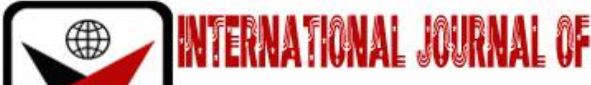

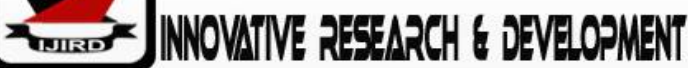

ISSN 2278 - 0211 (Online)

\section{Influence of Gross Domestic Product (GDP) on Real Estate Prices in Rwanda}

\author{
Habinshuti Philippe \\ Researcher, School of Business, Jomo Kenyatta University of Agriculture and Technology, Kenya \\ Dr. Mulyungi Patrick \\ Lecturer, School of Business, Jomo Kenyatta University of Agriculture and Technology, Kenya
}

\begin{abstract}
:
During the last two decades, Rwanda has experienced a rapid increase in the prices of real estate property raising concerns among policy makers and the government. The purpose of this study was to analyze the influence of the GDP on real estate prices in Rwanda case of Kigali City Urban Areas. The study adopted quantitative descriptive and correlational research designs. Quarterly time series secondary data was used for a period of 10 years from 2008 to 2017. Statistical tests of correlation, unit root, cointegration and causality tests were carried out during data analysis. The findings of the study were presented in form of tables and graphs. The findings indicated that GDP had significant influence on real estate prices. Findings further exhibit negative association between real estate prices and GDP. The study recommends the government to strive and achieve greater economic growth rate by encouraging investments in real property, increased supply hence reduced property prices.
\end{abstract}

Keywords: Gross domestic product, real estate market, housing price index, real property

\section{Introduction}

Globally, GDP and real estate prices are linked in a sense that GDP acts as an estimator for the progression of residential and commercial real estate markets. The long-standing relationship between a nation's economic footing as measured by its GDP and housing prices has been observed and studied over the past century by academicians as well as by private and public officials.

In the developed countries, it was recently shown that the rate of new home building was far outpacing natural demand, and exceeded demographic demand. There were a few signs of oversupply of housing units; in fact, levels were at near record lows, which were attributed to the intensity of the housing frenzy as opposed to any actual supply shortage. This frenzy was fed by an overzealous market that assumed incorrectly that housing prices would continue to escalate ad infinitum. According to another Economist article, "the total value of residential property in developed economies rose by more than $\$ 30$ trillion, since 2000 to over $\$ 70$ trillion, an increase equivalent to $100 \%$ of those countries' combined GDP's. Finally for developed countries it is projected that housing would soon cease to have a negative impact on GDP and become a positive contributor due to a significant drop in existing home prices that made it cheaper to own than rent.

On the African Market, the trend is not homogenous. Studies conducted in Kenya (Kibunyi D. (2015) and in Nigeria (Abiodun et al. (2017), concluded that the increase in GDP increases investment in real estate, supply increases and hence reduced estate prices. Therefore there is negative significant relationship between GDP and real estate prices

For the case of Rwanda, despite increased housing delivery, due to increased investment by commercial banks in housing and a buoyant construction sector (the fastest growing subsector of the Rwandan economy), housing remains unattainable for a large proportion of the urban population. And while it is estimated that by 2022 Kigali will require at least 344068 new units, only 37594 units will be delivered in the same timeframe should current delivery rates continue. (CoK, 2015).

Housing finance demand for both mortgage and microfinance has barely been met, and there is great potential for growth. More players are needed in the market to improve accessibility. As a top regional performer in reforming the macroeconomic environment, the state has performed its role as a market maker well.

Rwanda has achieved impressive development results over the past 20 years. However few studies have been able to analyse and explain the relationship between GDP and the real estate market. It is against this background that this study proposed a deep analysis to analyze that relationship and evidence based suggestions to different economic actors for effectiveness. 


\section{Statement of the Problem}

For the past 15 years, the real estate sector globally has experienced a rapid increase in prices, which has raised concerns, and several discussions have been done on the same about the sustainability of the sector. In rapidly developing cities in Africa, this increased prices overtime has attracted several investors into this sector with both local and foreign investors taking huge loans from financial institutions to construct houses. Studies which have been carried out in various parts of the world experiencing this scenario of price sky rocketing in the real estate sector has indicated mixed results as regards the causes of price increases in the sector. These causes range from economic, social to political factors. For example structural problems that could lead to artificially high house problems (Stohldreier, 2012), income and interests which may shoot up house prices in the long run (Vizek, 2010), economic fundamentals, diaspora remittance and cost of construction effects on real estate prices (Kibunyi, 2015) and existence of efficient markets which have corrective mechanisms to imperfections. Therefore, there is need for a study to clarify the real factors of real estate's prices especially in Rwanda.

Macroeconomic variables are the possible drivers of real estate prices. For example, lending rates in the financial institutions can influence the housing prices since they affect the cost of construction. Moreover GDP can also have influence on property prices since as economy expands the income increases possibly which may indirectly affect the property prices. Inflation not left behind can also be a determinant of property prices since it affects the cost of goods and raw materials used for construction. (Amos, 2015).Most of the studies that have been done in real estate sector exist in other countries as shown in the empirical literature with few in Rwanda focusing on microeconomic factors. (Pierre Kolowe, 2014). There is no study that has been done concerning the effects of macroeconomic factors on real estate prices in Rwanda. This study therefore has adopted macroeconomic approach by seeking to investigate the influence of macroeconomic factors on the real estate prices in Rwanda

The study was looking at answering to the question of how does GDP influence the real estate prices in Rwanda.

\section{Literature Review}

\subsection{Economic Growth Theory}

Robert Solow (1978) devised the "neo-classical" model of growth. According to the model, increased capital investment leads to an increase in growth rate temporarily due to the increased capital labor ratio with time. Therefore, the marginal productivity of capital declines bringing a same growth of real GDP as workforce plus a factor reflecting improved productivity. (Muthee, 2012). After wards, a steady-state growth path is eventually reached when output, capital and labour are all growing at the same rate, so output per worker and capital per worker are constant. (Muthee, 2012). Therefore according to Slow model, to achieve long-term growth trend in GDP requires an increase in supply of labour and higher productivity of labour and capital. This theory is relevant to this study since real estate is a form of investment and contributes greatly to economic growth of a country. Therefore in order to achieve higher productivity of labour and capital to raise economic growth it will attract more costs of attaining productivity and this adds to the price of real estate. Therefore as economic growth increases we expect the investment in real estate to increase and this will affect prices.

\subsection{Real Estate Valuation theory}

Property valuation process involves an estimation of the worth of a property based on prolonged experience and judgment through identification and assessment of property characteristics (Julius, 2012). The valuation is very important to all players in the property market such as the buyers and sellers, financial institutions, tax authorities and brokers in decision making process. The market value represents the most desired sales price for the property under competitive market conditions where demand and supply forces operate without interference. (Norman, 2009). In real estate valuation the appraiser's job is to determine the fair market value of the house, while the buyer and seller want to find, respectively, the lowest and highest feasible price for it.

(Brueggeman \& Fisher, 2015) proposes three approaches of property valuation estimation i.e. sales comparison approach, the cost approach and the income approach. The choice of a particular approach depends on property type and the purpose of the valuation. The sales comparison approach makes a comparison of selling prices of similar properties recently paid and makes adjustments for dissimilarities in property value estimation. The appraiser's objective is determining what the market considers to be recent and similar. (Julius, 2012)

The second approach which is the Income approach equates the market value of property to the present value of net future income flows from the property. The net income is equated to the gross income less overhead costs. The valuer compares the property in question with similar properties and determines the market discounts rate by analyzing recent sales of same properties in order to arrive at the net benefits of the property. (Julius, 2012). Finally the cost approach argues that replacement cost less depreciation equals the property value. This method is mostly used in insurance purposes where site clearance costs are added to cover the risks of fire on the building in addition to new constructions valuation. (Brueggeman \& Fisher, 2015) 


\section{Conceptual Framework}

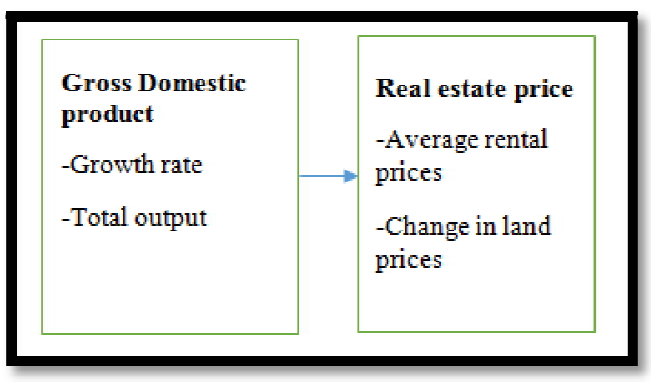

Figure 1: Conceptual Framework

\section{Empirical Review}

Adams \& Fuss (2010) carried a study on macroeconomic determinants of international housing markets. The study employed cointegration and VECM techniques in data analysis. The study was a cross-sectional involving 15 countries over a period of 30 years. The findings indicated that GDP growth has an increasing significant impact on housing market prices.

In a study on the determinants of housing prices in Europe, Egert \& Mihaljek (2008) concluded that GDP, Interest rates, inflation among others have played an important role in explaining the housing prices in both OECD and CEE countries. The study established a strong positive relationship between per capita GDP and house prices.

Ouma (2011) carried out a study on housing prices determinants in Nairobi Metropolitan suggested that residential house prices are not supported by GDP. GDP was found to have no role to play in their relationship with residential house prices.

A study was carried out in USA by Madsen (2012) on whether population growth affects housing bubbles. The study employed time series data and causality test and cointegration techniques were used in the analysis. The findings indicated that GDP had a strong positive influence on house prices though there was no evidence of housing bubble due to GDP.

Kibunyi (2015) investigated the real estate price determinants and if there is possibility of a bubble in Nairobi Kenya. The study employed correlation, cointegration and granger causality test models. The study found significant strong positive relationship between GDP and real estate prices. The cointegration results indicated a stable long run relationship between GDP and NSE index and the house prices.

A study was conducted by Tafirenyika and Paul (2017) in Namibia on the determinants of house prices and new construction activity. The study conducted an econometric analysis of endogenous and exogenous determinants of house prices and new construction activity in Namibia using restricted VAR model with a Johansen cointegration approach from 2000 to 2014. Results indicated that economic growth rate significantly and positively influence housing price index and construction activities. Granger causality results indicated bidirectional causality between the house price index and new construction activity in Namibia.

Muthee Karuana (2012) carried a study in Kenya on effect of macroeconomic variables on real estate prices. Descriptive research design was used and regression was also used to establish the relationship between macroeconomic variables and real estate prices. The study covered a period of ten years and monthly data was collected from secondary data sources.

Ouma (2011) carried out a study on housing prices determinants in Nairobi Metropolitan found that GDP have no role to play in their relationship with the residential house prices and so does construction costs. This conclusion seems to go out of sync with others since the expansion of real estate sector itself contributes to GDP expansion and therefore positive correlation is expected.

\section{Methodology}

This study used descriptive, quantitative and correlational research designs. The study targeted interveners in real estate market in Rwanda. Data related to economic fundamentals in Rwanda specifically inflation, GDP and interest rates were used.

The study utilized quarterly time series secondary data for the period 2008 to 2017 to achieve the research objectives. Secondary data is the data that is already collected and produced by others (Douglas, 2015). This is the data that was originally collected not for the purpose of the current research but for a different study done earlier. The secondary data sources include the government agencies, publications and reports among others. The data used in this research regarding economic fundamentals was retrieved from the data base of National Bank of Rwanda and National Institute of Statistics of Rwanda.

Quantitative data collected was analyzed by carrying out five statistical tests. These included correlation and regression tests, unit root tests, cointegration tests and causality tests. Correlation tests was carried out to measure the degree of association between real estate prices and GDP. Regression analysis was conducted to come with a model that shows the relationship between the independent and dependent variables in terms of the magnitude and the direction of change of dependent variable due to changes in independent variables. The regression model that was be used was of a linear form; $Y=\beta 0+\beta 1 \mathrm{X} 1+\varepsilon$ Where $\mathrm{Y}$ denotes real estate prices, $\beta 1$ coefficients of regression X1 denotes Gross Domestic Product and $\varepsilon$ denotes error term 
Philips Perron test was carried out to test for the stationarity of time series data. This is a preliminary econometric test that is conducted on secondary data in order to avoid spurious results which may lead to misleading conclusions. The test eliminates the effects of outliers in the data set used which may interfere with the results of the study. According to (Brooks, 2008), a stationary series can be defined as one with a constant mean, constant variance and constant autocovariance for each given lag. $\mathrm{HO}:(\alpha 0)=(\alpha 0,0,1)$ (Not stationary). Brooks C. (2008).

The alternative hypothesis $\mathrm{H} 1:(\alpha 0) \neq,(\alpha 0,0,1)$ (Stationary). If the test reveals that null hypothesis should be rejected then the variable will be said to be stationary.

Cointegration is the existence of a long run relationship among the variables. The researcher used Engel granger cointegration test method. The hypothesis to be tested will be, HO: there is no cointegration among variables. H1: There is cointegration among variables

Decision criteria: reject null hypothesis if the trace statistics is more than the critical value. Causality between two variables indicates the causation effect between the variables. Causality indicates whether the past values of a variable $\mathrm{Y}$ is able to predict the future values of a variable $\mathrm{Z}$. It further measures the direction of causation. The direction can be either one way or unidirectional. The researcher conducted Granger causality test to test for the causality between the variables.

The hypothesis to be tested for a case of two variables $\mathrm{Y}$ and $\mathrm{Z}$ is, $\mathrm{HO}$ : Y does not granger cause $\mathrm{Z} \mathrm{H} 1$ : Y granger cause Z Decision criteria: the null hypothesis was rejected if the $\mathrm{p}$ value is greater than $5 \%$ otherwise accepted

\section{Findings and Discussions}

Descriptive variables that the researcher computed included mean, standard deviation, maximum and minimum. The finding indicated that GDP average on studied period was 7.46 with the maximum of 11.17 and the minimum of 4.7 . The standard deviation was $1.78 \%$.

\begin{tabular}{|c|c|c|c|c|}
\hline & Mean & $\begin{array}{c}\text { Std } \\
\text { Deviation }\end{array}$ & Maximum & Minimum \\
\hline GDP & 7.46 & 1.78 & 11.17 & 4.7 \\
\hline \multicolumn{4}{c|}{ Table 1: Descriptive Statistics of Variables } \\
Source: National Bank of Rwanda
\end{tabular}

\subsection{Unit Root Test}

To avoid getting misleading results regarding the association of the concerned variables the researcher tested for unit root to ensure that the variables are non- stationary. This was achieved through the Philips Peron method of unit root testing. A stationary series exhibits a constant mean, variance and covariance. The researcher tested the following hypothesis for each variable. Ho Presence of unit root in the data set:1H No unit root in the data set Regarding the decision, the null hypothesis was to be rejected if the probability is less than $5 \%$ otherwise not.

\begin{tabular}{|c|c|c|}
\hline \multicolumn{3}{|c|}{ Phillips Perron test } \\
\hline & $\begin{array}{c}\text { Probability at } \\
\text { level }\end{array}$ & $\begin{array}{c}\text { probability at } \\
\text { 1st difference }\end{array}$ \\
\hline Housing index & 0.2088 & 0.0000 \\
\hline GDP & 0.1647 & 0.0001 \\
\hline
\end{tabular}

Table 2: Unit Root Test

Source: researcher's computation 2019

From the findings in the table 4.2 below, the probabilities for all variables at level are greater than 0.05 hence we fail to reject null hypothesis of presence of unit root therefore no stationarity at level. At the first difference, the probabilities for all variables are less than 0.05 hence we reject null hypothesis of presence of unit root and conclude that the variables are stationary at first difference.

\subsection{Cointegration Analysis}

Cointegration is the existence of long run relationship between two or more variables. The researcher achieved this by carrying out Engle Granger single equation test of cointegration. The findings are shown in the below table

\begin{tabular}{|c|c|c|c|c|}
\hline & tau-statistic & Prob* & z-statistic & Prob* \\
\hline GDP & -2.89 & 0.0456 & -11.77 & 0.0483 \\
\hline Housing index & -1.52 & 0.0484 & -3.81 & 0.0492 \\
\hline \multicolumn{4}{|c}{ Table 3: Cointegration Test } \\
Source: Researcher, 2019
\end{tabular}

The findings indicated that both tau statistic and z statistic have probabilities of less than 0.05 . This implies that or null hypothesis of series not cointegrated is rejected and we accept the alternative hypothesis indicating presence of series cointegration. From these findings we conclude that there exists a long run relationship between the GDP and real estate prices for the study period. 


\subsection{Granger Causality Tests}

This tests the causation between two variables. Granger causality tests explain using F-statistic whether lagged information on a variable Y provides any statistically significant information about a variable X. The researcher tested for causality between Housing index and GDP to ascertain whether there is one-way or two-way causation. The results show that the causation between Housing index and Bank rates and GDP is two way

\begin{tabular}{|c|c|c|c|}
\hline Null Hypothesis & Obs & F-Statistic & Prob \\
\hline $\begin{array}{c}\text { HOUSING_INDEX does not } \\
\text { Granger Cause GDP }\end{array}$ & 38 & 0.79477 & 0.0365 \\
\hline $\begin{array}{c}\text { GDP does not Granger } \\
\text { Cause HOUSING_INDEX }\end{array}$ & 38 & 0.69771 & 0.0456 \\
\hline
\end{tabular}

Table 4: Causality Test

\subsection{Correlation Analysis}

The researcher was interested in the association between the variables under study. Correlation analysis shows the strength and direction of association between two variables. Therefore the researcher conducted correlation analysis to ascertain the strength of association between real estate prices and GDP.

\begin{tabular}{|c|c|}
\hline GDP & HOUSING INDEX \\
\hline Pearson correlation & -0.546 \\
\hline \multicolumn{2}{|c|}{ Table 5: Correlation Analysis } \\
Source: Researcher's Computation 2019
\end{tabular}

The finding indicate that the Pearson correlation coefficients between housing index and GDP is -0.546 . This implies that there is a negative correlation between housing index and GDP.

\section{Discussions of Results}

The study found that there is negative significant influence of GDP on real estate prices in Rwanda. The Pearson correlation coefficient of -0.546 indicates that there is a strong association between GDP and housing prices. The multiple regression findings indicates that $1 \%$ change in GDP leads to a $2.5 \%$ significant change in estate prices keeping other factors constant. An increase in GDP growth rate leads to a decrease in real estate prices and vice versa. The granger cointegration findings indicate that there is a long run relationship between GDP and estate prices in Rwanda. Moreover granger causality results show that there is bidirectional causality between GDP and real estate prices. GDP growth signifies increased aggregate demand of the commodities in the economy i.e. expansion of investments, consumption, government spending and external market returns. Increased investment may be contributed by real estate sector hence increasing the supply. This may ultimately reduce the prices of real estates. These findings resemble the ones of Makena (2012) in Kenya who found significant negative influence of GDP on house prices. However the findings of this study contradict the findings of Tafirenyika and Paul (2017) who found a positive significant influence of GDP on housing prices.

\section{Conclusions}

The researcher came up with a number of conclusions based on the above findings.

- First there is a long run relationship between real property prices and the GDP. This is shown by the Engel granger cointegration findings where the null hypothesis of no cointegration was rejected.

- Secondly, there is high significant negative association between real estate prices and GDP. An increase in GDP leads to a decrease in real property prices.

From the regression coefficients findings, it can be concluded that $1 \%$ change in GDP leads to a change in real estate prices by $-2.5 \%$ ceteris paribus. Coefficients are significant for GDP.

- Lastly the causality findings imply that there is bi-directional causality between real estate prices and GDP.

\section{Recommendations}

The following suggested recommendations are deemed appropriate for implementation by policy makers based on the findings of this research.

The government should strive to achieve higher GDP growth rate by stimulating the demand aggregates like investments, government spending and external balance. Increased investments and expansion of government spending in infrastructure particularly real estate sector will increase the supply of residential property hence affordable housing prices

There is need for financial institutions to reduce the interest rates charged on loans advanced to the real property investors. This will go a long way in reducing the cost of construction and hence they are able to charge lower prices for the residential. Furthermore the reduced interest rates will encourage more investors in the real estate industry hence the supply of rental houses increases causing downward pressure on prices

\section{References}

i. Abiodun et al. (2017). Price Determination for Residential Property in Lagos Nigeria. The Principal-Agent Dillema. International Journal of Economy, Management and Social Sciences., 6(3),28-32. 
ii. Adams Z, Fuss R. (2010). Macroeconomic Determinants of International Housing Markets. Journal of Housing Economics, 19(1), 38-50.

iii. Agnello L \& Schuknecht L. (2011). Booms and bursts in housing markets: Determinants and Implications. Journal of Housing Economics.

iv. Amos. (2015). Effect of Macroeconomic Variables on Real Estate Prices in Kenya. Nairobi: University of Nairobi.

v. Basco S. (2014). Globalization and Financial Development: A model of the Dot-Com and the Housing Bubbles. Journal of International Economics.

vi. Brueggeman \& Fisher. (2015). Real Estate Finance and Investment. 14th Edition. Portland Oregon: Portland State University.

vii. C.R Kothari. (2011). Research Methodology. Methods and Techniques. New Delhi India: New Age International Publications.

viii. Calza et al. (2013). Housing Finance and Monetary Policy. Journal of the European Economic Association.

ix. Centre for Affordable Housing Finance in Africa. (2016). Understand Rwandas housing Finance Market. Kigali: CAHA.

x. Creswell et al. (2018). Research Methodology. Methods and Techniques. New Delhi India: New Age International Publishers.

xi. Douglas M. (2015). Sources of Data. Retrieved on 22nd September, 2018 from http//www.onlineetymologydictionary/data.

xii. Erika Luitjens. (2016). No housing bubble in rwanda. Daily Posts. Kigali: CAPCON Foundation.

xiii. EuropeAid. (2014). Housing Market Demand, housing finance and housing preferences for the city of Kigali.

xiv. Hass Consult. (2016). House Price Index in Kenya Quarter one 2016. Nairobi: The Hass Property Index.

xv. Julius Makena. (2012). Determinants of Residential Real Estata Prices in Nairobi. Nairobi: University of Nairobi.

xvi. Kibunyi D. (2015). Real Estate Prices in Kenya. Is there a Bubble? Nairobi: Strathmore University.

xvii. Madsen. (2012). Does Population Growth affect housing bubbles? A study on Population growths influence on the US housing Market during the 2000's. Bergen: Norwegian School of Economics.

xviii. Mahalik \& Mallick. (2011). What Causes Asset Price Bubble in an Emerging Economy. Some Empirical Evidence in the Housing Sector of India. International Economic Journal, 25(2), 215-237.

xix. Masika. (2010). Hedging Housing Risk. Journal of Real Estate Finance Economics., 43, 87-92.

xx. Mugenda \& Mugenda. (2013). Research Methods: Quantitative and Qualitative. Nairobi: African Center for Technology.

xxi. Muthee Karuana. (2012). Relationship between Economic Growth and Real Estate Prices in Kenya. Nairobi: University of Nairobi.

xxii. Norman et al. (2009). House Prices and Economic Growth. Journal of Real Estate Finance and Economics.

xxiii. Omboi B. M. (2011). Factors Influencing Real Estate Propert Prices: A survey of Real Estates in Meru Municipality, Kenya. Journal of Economics and Sustainable Development., 2(4), 1-21.

xxiv. Rahi S. (2017). Research Design and Methods. A Systematic Review of Research Paradigms, Sampling Issues and Instruments Development. International Journal of Economics and Management Science.

xxv. Tafirenyika \& Paul. (2017). Determinants of House Prices and New Construction Activity. An Empirical Investigation of Namibian Housing Market. The Journal of Developing Areas, Vol 51 No 3.

xxvi. Ouma O.P. (2011). Real Estate Prices and Economic Fundamentals. An Empirical Investigation of the Residential Housing Market in Nairobi City. Nairobi: Strathmore University. 